\title{
Education of Nobility: An Unique Life of the Court as its Foundation in Heian Japan
}

\author{
Ajoy Kumar Das
}

\begin{abstract}
Department of Japanese, Visva-Bharati, Santineketan, West Bengal, India
Corresponding author: ajoykumar.das@visva-bharati.ac.in
\end{abstract}

Received: $10-10-2020 \quad$ Revised: $23-11-2020$

Accepted: $10-12-2020$

\begin{abstract}
Schools as institutions of education were first established in Heian Period (794-1185). In the capital a college termed daigaku, and in the provinces provincial schools called kokugaku, were set up. The nobles studied poetry and music following the pattern of study of T'ang China. The system of schools based on T'ang system and the schools of the capital were very well organized for the children of the nobility. It appeared that the education of the nobility took an extremely classical form based on Chinese classics. This article deals with various aspects of Heian education system characterized by Chinese and Japanese classics. The main objective of this paper is how the education of nobilities played an important role in unique life of the court noble that had the power to govern and how the education of the nobility was unique in having the life of the court as its foundation.
\end{abstract}

Keywords: Taiho Code, Heian Education, Nobility, Daigakuryo, Kokugaku, Curriculum, Kukai, Worship Customs, Waka, Manyoushu, Calligraphy, Music

An important aspect of the education of the nobility lies in their schools which were set up and administered as a national system in Heian period (794-1185) in Japan. The establishment of the national school system is attested to in the provision of the education law of the famous Taiho Code (A.D. 701) in accordance with which a college was founded in the capital and in each of the provincial areas. From these institutions schools for educating the aristocrats developed.

However, it is generally much earlier than the promulgation of this law. It is said that Horyu Gakumonji (Horyuji temple was a monastic school and it did not belong to any particular sect of Buddhism at that time) set up by Prince ShotokuTaishi was first. However, this school was merely for study in the Temple. It cannot, therefore, be considered as an independent school in the ordinary sense of the word. Although it can be inferred that scholars who came to Horyuji from Chinese continent gave scholarly lectures, it had not yet become reorganized as a regular school.

In this period, there are notations concerning the various arts. These are divided generally into scholarship and music. Scholarship was regarded as very important in the education of a noble person. One could not comprehend classical learning without study. In the study of music, it was required that one be well versed in at least one repertoire. Chinese poetry and calligraphy were similarly indicated as necessary requirements in the art. These notations reveal the various artistic skills which the aristocrats were to possess. Through these we can observe what kind of learning comprised the education of a noble of that time. At that time noble ladies were also required to have skills in

How to cite this article: Das, A.K. (2020). Education of Nobility: An Unique Life of the Court as its Foundation in Heian Japan. Educational Quest: An Int. J. Edu. Appl. Soc. Sci., 11(4): 193-196.

Source of Support: None; Conflict of Interest: None $\infty$ 
calligraphy, the composition of Japanese poems and other arts.

\section{Educational institution in Heian}

The first school in Japan was the institution which is thought to have been established at Omi in the time of Emperor Tenchi (A.D. 662-671). A note concerning this school in the preface of the Kaifuso relates that schools were established at that time and there was considerable progress in education. It is also evident that schools were set up and administered by the Imperial Court. Soon thereafter, in the fourth year of Emperor Temmu (A.D. 676), we are told that a college with professors and students who pursued academic learning already existed. Since we can affirm the existence of a so called daigaku or collage in this period, we may also safely infer that a school corresponding to the daigakuryo or collegehouse had already been established previously in the capital from the time of Emperor Tenchi (A.D 662-671).

It was this institution which was later stipulated by the school law in the Taiho Code, and for a long time it played a central role in the education of the aristocratic class. Turning to the function of the daigakuryo as an educational institution for the nobility, we may observe that according to the personnel regulation of teachers and administrators provided in the Taiho Code, there were various administrative officials, each having a title such as daigaku-no-kami (rector), suke (vice-rector), tai-jo (upper head), sho-jo (lower head), tai-sakan (upper sub-official) and sho-sankan (lower sub-official).

In addition, it was stipulated that there should be appointed one professor, two assistants, and four hundred students of classical learning; two professor of music; two professors of literature and calligraphy; two professors and thirty students of mathematics. The professors and their assistants engaged in the actual teaching. Later, such positions as myohohakase (doctor of laws), kidenhakase (doctor of history), and bunjohakase (doctor of literature) were formulated and the scope of instruction in the daigakuryo broadened. Fourfold division of the arts consisted in the interpretation of Confucian scriptures (myokyo), interpretation of law (myoho), composition (monjo) and mathematics (san). The study of monjo regarded as most important.

\section{Features of Teaching-Learning and Curriculum}

The students who enrolled in the daigakuryo were children from fifth rank and above as well as those of the Fubitobe (learned men) of YamatoKawachi. If the children of those persons above the eighth rank expressed a desire, they could also be enrolled according to regulation. Students were required to master one of the following classical texts: Shueki, Shosho, Shurai, Girai, Raiki, Moshi, and ShunjuSashiden. At the time every student learned Kokyo and Rango. These ancient classics were classified into Daikyo (Great Classics) including Raikiand ShunjuSashiden, the Chukyo (Middle Classics) which is comprised of Moshi, Shurai and Girai, and Small Classics) which includes the Shueki and Shosho.

While the curriculum was organized according to these divisions, the level of scholarship was determined by what texts the student had mastered. At a later time the required length of the time for the study of each classic was fixed, and the standard for promotion established. After becoming able to read the classics, the students would discuss their meaning. Every ten days there was a one day vacation. The day before there would be an examination.

Furthermore, at the end of the year there was a test over all they had been taught. For those who tried to become public officials a promotion system in imitation of the T'ang was applied after they become well-versed in more than two Chinese classics. There were six types of tests, namely, Planning and Strategy (shusai), Chinese Classics (myokyo), Politics (shinshi), Law (myoho), Calligraphy (sho) and Mathematics (san). Individuals were divided into ranks according to their merits in each of these areas. It became a principle that one received his rank according to his depth of scholarship.

The provincial schools were institutions of learning provided for those living in the respective provinces. There were differences between the Dazaifu (An early government office for military and diplomatic service, established by the Yamato court in the present town of the same name in Kyushu) and each province concerning the way in which the provincial schools were set up. Since the school of Dazaifu was set up for the sake of the entire Kyushu area, the 
organization was larger and included one professor, one teacher of on'yo (astrology and calendar), two medical doctors, and one doctor of mathematics. In the provincial schools there was a provincial professor and a doctor of medicine.

Besides the children of the country head who were allowed to enter the school, the most intelligent children between thirteen and sixteen years of age were also permitted to attend. The students consisted of fifty from the greatest provinces, forty from the greater provinces, thirty from the middle-sized provinces and twenty from the small provinces. It was also determined that one fifth of the students must take the medical course.

A summary of the regulations governing the curriculum of the college and the provincial schools indicates that divination and medicine were offered in the provincial schools, while these studies were carried out in the capital in several schools apart from the daigakuryo. Consequently, the Taiho Code made the classics central in the educational curriculum of the daigakuryo in the metropolitan area. However, the provisions of the code generally extended to the various other schools in the capital.

The schools of the capital were very well organized for the children of the nobility. However, this system of schools based on the Tang system could not be permanently enforced just as it was. The daigakuryo did not flourish greatly, and appears to have been declining even when Fujiwara no Muchimaro became Vice Rector in Taiho Period (701-703). Nevertheless, it is particularly noteworthy that until it was destroyed by the fire it continuously functioned as the school of the capital.

The children of the nobility lived in the daigakuryo and lodgings where they could pursue their studies were provided. These were called zoshi (Dormitories and places of study). There were two kinds of zoshi: the jikiso established within the college and the besso outside the daigakuryo. The earliest among the besso was the Kobu'in of Wake no Hiroyo. This was the residence for the students of the Wake family, and it was located south of daigakuryo. To pursue their education the children of the Wake clan commuted to the daigaku where they received instruction from the professors. The Kangaku' in was the largest and most famous among the besso and it continued the longest. This was the zoshi for the students of the
Fujuwara clan. In addition, there were other zoshi such as the Shogakuin of the Ariwara clan and the Gakkan'in of the Tachibana family.

These academic were established in affiliation with the daigakuryo which was a national institution. Besides these, there were other privately established schools. A representative one was the Shugeishuchiin established by priest Kukai. It was Kukai's idea that the culture of a country could not be made to flourish in such a situation. Therefore, he copied the method of the village school of the T'ang and constructed places of study through which he tried to give the opportunity of education to the greatest number of people.

Educational institutions of the capital which centered in the daigakuryo, it appears that the education of the nobility took an extremely classical form based on the Chinese classics. However, the nobles did not intend to base the education of their children on such scholarship alone. As children of the nobility, they also had to have a broader cultural education for life in the court. These studies were Court Practice (yusokukojitsu), Rhetoric (monjogaku), Chinese Poetry (shigaku), Japanese Poetry (kagaku) and Calligraphy (shodo).

Yusokukojitsu is learning related to court ceremonies and worship customs. It had been organized based on the daily practices of each aristocratic family and the regular and annual rituals in the court. Monjogaku and composition was especially highly regarded in the daigakuryo. The professor of monjogaku received a high rank of Chinese classical literature. The composition of Japanese poems waka was also highly regarded in the education of the aristocrat and even considered as the symbol of his way of life. Many collections of poetry were used as text books. The Manyoshu and the Kokinshu were held most fundamental. Calligraphy could not be separated from the practice of poetry, and waka formed an important element in the education of the nobles.

\section{Artistic Achievements of Nobles}

Lessons in penmanship began with the practicing simplified letters of kana, employing the Japanese alphabet. After mastering the lessons, they practiced cursive penmanship by copying waka poems. In case of boys it was required to learn to write Kanji (Chinese characters), first learning the semi-cursive 
(gyosho), then progressing to cursive (sosho) and standard style (kaisho). Poems were frequently used as material. Such works as the Anthology of Japanese and Chinese Poems provided important materials for the practice of calligraphy. The three aspects of the position, motion and touch of the brush were especially valued in the method of writing, and the students applied themselves diligently to their practice.

Along with the learning and composition of poems, music was one of the necessary requirements of the nobles. The nobles were endowed with these three talents like shi-ka-kangen or poem, song and music were respected and called sansen-nozae or talent of three ship. Besides scholarships and poetry, kangen or music was esteemed in the education of the aristocrat. This musical sphere of education was called kangen. Here various teachers of musical instruments were designated. Students who wanted to study particular musical instruments were attached to those teachers. It was a system relative to the education of musicians or specialists in music. Hence, it must be considered separately from the general musical training of the children of the aristocrats.

The instruments most used at the time of familiar to the children of the nobles were harp (koto), flute (fue), and lute (biwa). Among the types of koto, wagon, so and kin can be distinguished. Beside these they also learned the biwa and taiko (drum). In order to learn these, they had excellent instruments and chose famous artists as teacher. However, some musical forms could be mastered only after life-long training. Apart from that they learned such things as drawing, incense mixing, cooking, football, falconry, archery and horsemanship as artistic achievements of the nobles. In this way they used to gather their several abilities.

Education in katachi or bearing comprehended everything from dress and its ornaments and the manner of wearing them to one's whole appearance and deportment. It was required that individuals be superior even in their appearance or bearing. Education in these aspects was achieved naturally in their homes and by participating in various functions in the court and in the homes of influential families.

\section{CONCLUDING REMARIS}

From this study it is revealed that the aristocrats, during Heian period formulated such education peculiar to the nobility. At that time the common people looked upon the noble as his superior, and they demanded an education following a pattern similar to that of the nobility. Consequently, in order to judge whether or not a person had a high education, one employed these patterns of the nobles as criteria. As is mentioned above, the nobles said those who excelled in poems, songs, and music were endowed with talent of three ships. Among the narratives of life during this period, there are some stories in which common people who excelled to some degree in those arts attained great frame by their skill. This indicates that the people of that time achieved an education based entirely on the educational methods of the nobility.

Therefore, the education, which the nobility who had the power to govern devised from within their own way of life, determined the method which become the basis for the education of men generally in that age. The Education of the nobility was unique in having the life of the court as its foundation, but the education required of these aristocrats also becomes the basis for the way of thinking concerning education for all persons during this time.

\section{REFERENCES}

Benedict, Ruth. 1987. The Chrysanthemum and the Sword, Charles E. Tuttle Company, Japan.

Dore, R.P. 1965. Education in Tokugawa Japan, University of California Press.

Duke, B. The Japanese School: Lessons for Industrial America. New York, Praeger.

Goodman, R. 1990. Japan's International Youth: The Emergence of a New Class of Schoolchildren. Clarendon Press. Oxford.

Hall, John Whitney. 1991. Japan from Prehistoric to Modern Times, center for Japanese Studies, the University of Michigan, Ann Arbor, Michigan.

Lois, Peak. 1990. Learning to Go to School in Japan, University of California Press.

Lynn, R. 1998. Educational Achievement in Japan: Lessons for West, Macmillan, London.

Kodansha Encyclopedia of Japan, Kodansha International Ltd., Tokyo, 1983.

Kobayashi, T. 1976. Society, Schools and Progress in Japan. Pergamon, Oxford. 